\title{
OCCURRENCES: THE WORLD TRADE CENTER INSURANCE QUESTION
}

\section{Desmond Keith Derrington*}

On September 11,2001, an aircraft flew into one of the main towers of the World Trade Center complex, causing severe immediate damage to it, but not to the other main tower in the complex. About seventeen minutes later, a second aircraft flew into the other tower, also causing severe immediate damage to it. Later, but as part of the continuous progress of the initial damage, each tower collapsed, causing further catastrophic damage to the point of total destruction of the towers and other associated buildings.

The attack involving each aircraft was thought to be, and for present purposes may be accepted as having been, intentional and part of a larger coordinated act of terrorism directed at both towers and certain other targets of political significance.

The complex was insured under a policy that was unlimited in the aggregate but limited to US $\$ 3.546$ billion for "any one occurrence." That limited figure will probably not be sufficient to cover the loss of either building, much less the loss of both. The issue presently being litigated between the insurers and the insured is whether, within the meaning of the policy, there was one occurrence or two.

The general thrust of the insured's argument is obvious - that there were two separate occasions of destruction at different times when different aircraft destroyed different buildings. Since they were physically separate, it is irrelevant, except that both buildings came within the coverage of the same policy, that they were part of the same complex. In the event of real ambiguity, it might also be argued, the contra proferentem principle will resolve the issue in favor of the insured. In the United States, there seems to be greater resort to this rule ${ }^{1}$ than in Australia $^{2}$ or England, where it is regarded as a rule of last resort; but in this case it may even come to that. It

* The Honorable Mr. Justice Desmond Keith Derrington was appointed as Justice of the Supreme Court in Queensland, Australia in 1982. He served until 2000. The Honorable Mr. Justice Derrington received his Bachelor of Laws from the University of Queensland and was admitted as Barrister-at-Law in 1954. He received his commission as Queen's Counsel in 1973. He currently teaches law at his alma mater, the University of Queensland, Australia. The Honorable Mr. Justice Derrington has published extensively on the law of liability insurance and is a frequent guest speaker at national and international conferences. He was a Visiting Fellow at Wolfson College, Cambridge in 1993 and a Visiting Scholar at Cornell University in 1995.

1. See, e.g., Westchester Resco Co. v. New England Reinsurance Corp., 818 F.2d 2, 3 (2nd Cir. 1987).

2. See the review of the principles applicable to the resolution of ambiguities of interpretation collected by Kirby, J., in Johnson v. American Home Assurance Co. (1998) 192 CLR 266, 272-76. 
would of course work in favor of the insured if this terminology of the policy had been proffered by the insurer. ${ }^{3}$

The construction point would be far more satisfactorily resolved if that can be achieved according to more satisfying, that is, substantial, canons of construction associated with the objective ascertainment of the common intention of the parties by reference to the words that they used. Again in the United States, the reasonable expectation of the insured plays a greater part in the construction of insurance policies than it does in Australia or England. This is somewhat more meritorious than the contra proferentem rule, but justification for its invocation here may be also prove to be doubtful because this insurance contract may well have been negotiated at arm's length by the insured's professional advisers. In that case, there is room for the countervailing argument that if there were any expectation, then the advisers would have ensured that the policy said so; and it does not. However, other related rules and reasoning of the more persuasive kind are certainly available. Together they require the word, "occurrence" to be construed in its circumstantial as well as its grammatical context, and with reason and commonsense in the light of the commercial purpose of the contract.

In Australian Casualty Co. v Federico, ${ }^{4}$ Chief Justice Gibbs confirmed that the ordinary rules of construction applied to a policy of insurance so that, as in the case of any other commercial contract, a court may take the more reasonable of two alternative interpretations that are open on the words used. That is, one that is more in accord with the probable intention of the parties. He noted specifically that "the trend is, if anything, to adopt a liberal interpretation in favor of the assured so far as the ordinary and natural meaning of the words used by the insurers permits this to be done."

The insurers' argument will probably be that the acts of destruction were simply different manifestations and part of the same event or occurrence ${ }^{6}$ because they were orchestrated and related parts of the same attack and took place within the same time frame and at the same location. This has been called 'The Pearl Harbor Concept.' That is, that all the occasions of destruction were merely incidental parts of an integrated and continuous attack involving a number of aircraft, and it is immaterial that they engaged in separate acts of destruction. This will be more fully discussed below, but it is beneficial at this stage to understand the thrust of the essential issue.

3. Whether it was so proffered is not known. In an insurance contract of this size, the insured's broker frequently submits terms, and it is not inconceivable that this applied to the relevant clause.

4. See Australian Casualty Co. v. Federico (1986) 160 CLR 520 (referring to the citation in Mt. Albert City Council v. New Zealand Municipality Co-operative Ins. Co. Ltd. (1983) NZLR 193; 25 HALSBURY's LAWS OF ENGLAND, \$ 594, n. 1 (4th ed.)).

5. Id.

6. See Hartford Accident \& Indemnity Co. v. Wesolowski, 305 N.E.2d 907 (N.Y. 1973), 33 N.Y.2d 169, 172-73. In New York the terms seem to be largely interchangeable with accident and with each other. See id. 
The construction of the policy in this case will depend on the terms of the insuring clause, as influenced by other related contextual features, ${ }^{7}$ and it is this latter feature that renders some authorities valueless or less valuable because of the differences in this respect that will be found in them. ${ }^{8}$ The words will not be given any technical or strictly grammatical meaning that conflicts with its purpose, as the parties should have understood it, in the factual context in which the contract was made. Its commercial purpose was plainly the protection of the insured against the risk of loss through the damage to or destruction of all or part of the several structures of the complex, and it is to that purpose that occurrence must be related. ${ }^{9}$ Equally, the insurer's purpose in limiting the risk to which it was exposed and upon which it assessed the premium must be accorded appropriate weight.

Even if there had been an express expansive or limiting definition of the term, or perhaps one that makes it mean something that it does not ordinarily mean, this too must undergo the construction process in which these other influences may operate. The contextual influences include the influence of other provisions of the policy, or implications to be drawn by the specific usage of the term in the provision. The relevant commercial purpose will vary

7. See Montrose Chemical Corp. v. Admiral Ins. Co., 913 P.2d 878 (Cal. 1995).

8. For example, in Government Ins. Office of NSW v. Leighton-Atkinson Joint Venture (1981) 146 CLR 206, where the term, occurrences in a deductibles clause was considered, it was referred to as arising out of a number of what were described as causes, which clearly implied that the causes could not be the occurrences referred to. See id. Further, the causes were successive but quite distinct storms. See id. In each relevant issue the occurrences were a serious storm that caused damage to the property, followed by less severe storms while it was under repair causing further damage to the property that would not have occurred but for the original damage. See id. Consequently, the analogy breaks down to some extent by comparison with the position that would have obtained if the damage had been sustained at various times during one storm. In a number of other cases such as Axa Reinsurance (UK) Ltd. v. Field (1996) 1 WLR 1026, (1996) 3 All ER 517, the waters are muddied by the presence of an additional feature aggregating the losses of occurrences arising from one originating cause, but it is still possible to obtain some assistance from the Courts' treatment of 'occurrences' before considering whether they arose from a common cause. See id.

9. See Forney v. Dominion Ins. Co. Lud. (1969) 1 WLR 928, 934; (1969) 1 Lloyd's Rep 502, 508; Kuwait Airlines Corp. v. Kuwait Ins. Co. Ltd. (1996) 1 Lloyd's Rep 664; Dawson's Field Award (29 Mar. 1972) discussed in Kuwait Airlines Corp. at 685; Distillers Co. Biochemicals (Aust.) Pty Ltd. v. Ajax Ins. Co. Ltd. (1973) 130 CLR 1; Mann \& Holt v. Lexington Ins. Co. C.A. 256 para. 36 (C.A. Civ. 2000); (2001) 1 Lloyds Rep 1; 1 All ER (Comm.) 28 (which was a first party policy for the protection of property). See also Gann v. Tai Ping Ins. Co. Ltd. (1999) 2 All ER (Comm.) 54; Groupama Navigation et Transports v. Catatumbo CA Seguros (1999) 2 All ER (Comm.) 970; (2000) 2 All ER (Comm.) 193. There is some apparently conflicting dicta in Schiffshypothekenbank Zu Luebeck, A.G. v. Norman Philip Compton (a.k.a. "The Alexion Hope" case) (1988) 1 Lloyd's Rep 31 1, 319 (Nourse, L.J., stated that it was not necessarily an adventure or a peril but in Kuwait Airlines Corp., Rix, J., did not regard this as any inhibition from considering the term from the point of view of the insured). 
according to the peril insured against. ${ }^{10}$ In this case, the peril is the insured's loss from damage to or destruction of the property through the risks described.

Sensibly, because of the multiplicity of occurrences that may be associated with a loss, the term must have some restriction on its scope, and if this is not express, it should be implied as a matter of ordinary practical business necessity. First, the occurrence referred to must be associated with the insured risk; and, secondly, that association must be causal, for a mere temporal nexus would have no rational point to it. The causal connection adopted in insurance law, in the absence of expression to the contrary, ${ }^{11}$ is proximate cause. ${ }^{12}$

For example, in liability insurance where the peril is the insured's loss through incurring liability to a third party, that occasion of incurring liability is the occurrence. It is not the insured's wrongful act but the infliction of harm on the third party that attracts the insured's liability, which may sometimes be separate from the wrongful act, and much later. ${ }^{13}$ Similarly, even though occurrence may be defined by the policy to include continuous or repeated exposure to substantially the same conditions, this would not bring multiple claims within the class of a single occurrence simply because they can all be traced back to a single action or decision such as the insured's or another's decision to follow a single course of conduct. ${ }^{14}$

Under the policy in the present case, the extent of the insurer's liability to indemnify was to be limited to the stipulated sum per occurrence, but the complex consisted of several structures, and the aggregation of claims under the policy was unlimited. There can be no argument that the parties contemplated the possibility that during the policy period there could be separate occasions of damage to different components of the complex, each

10. The court will construe a term in the light of the hazard insured against. See Champion Int'l Corp. v. Continental Casualty Co. 546 F.2d 502, 505 (2nd Cir. 1976); Union Carbide Corp. v. Travelers Indemnity Co. 399 F.Supp 12, 17 (W.D. Pa. 1975); Transport Ins. Co. v. Lee Way Motor Freight Inc. 478 F.Supp 1325 (D. N.J. 1980).

11. Such a contrary expression sometimes appears in relation to a reference to a series of occurrences that, for example, may be specified as arising from the same original cause. That is a different point.

12. See Lawrence v. Accidental Ins. Co. (1881) 7 QBD 216, 220; Becker Gray \& Co. v. London Ins. Corp. (1918) AC 101; Lloyds TSB General Ins. Holdings Ltd. v. Lloyds Bank Group Ins. Co. Ltd. C.A. 1643 \& 42 (Cal. Civ. 2001).

13. See Remmer v. Glen Falls Indemnity Co., 295 P.2d 19 (Cal. Ct. App. 1956); Montrose Chemical Corp., 913 P.2d at 878; Distillers Co. Biochemicals (Aust.) Pty Ltd. v. Ajax Ins. Co. Ltd. (1974) 130 CLR 1 (where the various incurrence of liability by the insured was the result of its distribution of a drug, but that was not the "occurrence" though it was the common factor that caused the infliction of harm on the various consumers of the drug that was the basis of the insured's liability to be regarded as a series).

14. See Stonewall Ins. Co. v. Asbestos Claims Management Corp., 73 F.3d 1178, 1212 (2nd Cir. 1995). But see Consolidated Edison Co. v. Employers' Ins. Co. of Wausau (1997) WL 727486. 
up to the amount of the limit. The insured will argue that this is their understanding of the terms of the agreement upon signing it.

The precise circumstances of this terrorist attack, and particularly the possibility that two aircraft would be flown into the two towers, ${ }^{15}$ were surely unforeseen by the parties. However, they would have considered the possibility of some form of terrorism because of past unhappy experience at the same property. ${ }^{16}$ The present issue would not have been considered absurd if it had been raised when drafting the policy. The possibility that both major buildings would be the targets of a coordinated attack would have been a foreseeable risk, even though outside the range of past experience. This is the general set of background circumstances known to both parties on which they based their contract.

When it is used in a policy, the word, occurrence, may be used to identify the trigger of coverage, or it may be used as a factor in the limitation of the amount of the coverage; and, in a vertical division of coverage, it may establish when an underlying coverage will be exhausted and the next layer begins. It may also be used to identify the occasion for the application of a deductible. Although this form of machinery may benefit one party over another in a particular case, it may not necessarily do so generally. Its favor may depend on the exigencies of the particular occasion. There is nothing unfair about this since the possibility of benefit may be offset by the possibility of detriment. Even if that is not so, it may be balanced by other considerations when the parties set the terms of their agreement, for example, a lower premium.

When it is used in this way, occurrence is flexible and adaptable to different usages, and it is for this reason that in any particular case contextual factors and/or the circumstantial matrix of the contract, including its commercial purpose, may influence its connotation. As it has been indicated above, the commercial purpose in this form of insurance is the protection of the insured against loss through the destruction of or damage to its insured property, and so in that context, "occurrence" must refer to the happening of damage or destruction to that property. For example, in the case of a planned hi-jacking and subsequent destruction of the aircraft, in respect of the insurance of the aircraft's owners, neither the plan nor the hijacking would be the "occurrence" within the terms of such a policy since that would not have come about until the occasion of destruction. ${ }^{17}$

In some usages, the word will expressly refer to the happening of the harm as the peril insured against. In respect to this dispute, "occurrence"

15. The possibility of collision by an aircraft was foreseen by the architect in the precautions taken in the construction of the buildings. There had been an earlier occasion when a small aircraft had collided with the Empire State Building.

16. There had been an attack by the use of a car bomb in the basement parking garage of one of the buildings.

17. See Caudle v. Sharp (1995) LRLR 443 per Norse, L.J.; Kuwait Airlines Corp, at 684. 
would mean that the occasion of destruction by each aircraft would be an occurrence within that meaning. In other usages, the same may be implied, such as when the "occurrence" is referred to as the result of an identified cause, for example, 'an occurrence arising out of a terrorist attack.' In such an expression, the occurrence cannot be the same thing as the cause out of which it arises.

If a usage has the effect of equating the term with a larger cause of the loss rather than an immediate and direct cause, it is the force of such an implied definition that has that result. However, its presence may imply that but for that presence, the occasion of each infliction of loss would be an occurrence within the ordinary meaning of the term. Alternatively, it may still be possible to argue with merit that when the term is identified with the cause of the loss, it may be confined to the proximate cause, the immediate and direct cause that results in each occasion of harm, and that it is only the reference to a 'series of similar causes' that has the expansive effect of the definition. ${ }^{18}$ Except when the terms of the contract otherwise require, insurance law looks to proximate cause and does not trace causation back to its metaphysical beginning. ${ }^{19}$

In other usages, an occurrence may be expressly defined to include all losses or damage attributable to a single cause or a series of similar causes. This is useful, and primarily designed, to control the case where there are a number of small repetitive inflictions of harm from a repetitive or continuing cause. This might be suggested to apply to the present circumstances in that the successive destructive events were the repetition of the continuing cause, namely, the terrorist conspiracy. That would depend on whether the conspiracy was the "cause" referred to. In the former sense, it would protect the insurer from a large claim exceeding the limit but made in the form of a large number of small claims that do not exceed it; and the insured would benefit in respect of the application of the same reasoning to the deductibles clause.

It helps in the construction process to consider how the parties would have relevantly interpreted the contract, as they should have objectively understood it, if at the time of its formal completion, they were asked the meaning of its words in relation to circumstances broadly of this nature. At that time, their minds would have been focused on the commercial purpose of the contract, which was to provide protection of the insured against such risks within the limits of the cover. Conversely, any limit on its amount was to afford reasonable protection for the insurer, associating the extent of its obligations with the amount of the premium charged. For example, if the loss

18. See Lloyds TSB General Ins. Holdings Ltd. v. Lloyds Bank Group Ins. Co. Ltd. C.A.1643 § 42 (Cal. Civ. 2001).

19. See Album Realty Corp. v. American Home Ass. Co, 607 N.E.2d 804 (N.Y, 1992), 80 N.Y.2d 1008, 1010; 592 N.Y.S.2d 657, 658 (1992). 
from one of these destructive incidents had exceeded the limit, as it may well have done, then there is clear opportunity for the application of the limit.

It is instructive to contemplate the consequence if there had been but one incident that directly destroyed only one building, but its collapse had then destroyed the other building. The element of unity inherent in such a connection and continuity would have meant that there was only one "occurrence," and the consequential destruction was part of it. This is in fact what happened to other of the minor buildings of the complex, but it did not happen in this way in respect of the two major buildings. There were two distinct occasions of destruction in the sense that the second did not flow on from the first, and they required two distinct acts to cause them. Insofar as the loss to which the limit is applied must be causally linked to the "occurrence" referred to, it is also plain that the proximate cause of each loss was a separate act of actual destruction, and that the overall terrorist plan that orchestrated them both was at one step more remote. Further, it was at the point when the first act of destruction was perpetrated that the insurer became liable for that loss and all loss consequent on that destructive happening. ${ }^{20}$

The implications of this are consistent with what would have been the answers given by the parties at the time of the contract if they had been asked the question posited above. The term had multiple interconnected purposes. It identified the monetary limit, which was for the insurer's benefit; but it also meant that if there were more than one occurrence, then the limit would not apply to the totality of the indemnity to be provided under the policy. While the insurer's interest in having a limit of liability for any one occurrence had valid objective importance within that intended scope, the insured's interest in protection against multiple losses must have been of manifest importance. When the issue of singularity or multiplicity arises, as distinct from the limit within a single occurrence, the insured's interests might be thought to have been logically dominant at that point.

This is demonstrable further by reference to the other aspect of limitation of the amount of the indemnity. As the explicit terms of the cover show, the insurer did not seek to have the protection of a limit in respect of multiple losses that might rise from separate occurrences. Consistently, when the issue is not the limit for a single loss but whether there is more than one loss, the protection reserved by the insurer for itself should not be given a tortured extension, or even a liberal reading, as against the insured

On the issue as to the limit in respect of a single loss, the limitation should be read in a way that serves it plain purpose for the insurer's benefit, so far as it goes; but on the issue of what is meant by its reference to

20. In Kelly v. Norwich Union Fire Ins. (1990) 1 WLR 139, Croom-Johnson conveniently voiced the obvious when he stated that: "[The word 'events'] referred to any of the events which bring about the liability of the insurance company once the policy has become effective." Id. at 146 . He was dealing with a different situation where the damage was not necessarily the peril covered. 
indemnity per occurrence, it should not be read so liberally. As it has been explained, the thrust of its structure and expression is that at this point the limitation on the extent of the insurer's obligation is itself being delineated. Its purpose at that stage is the establishment of the range of the insurer's benefit from the term. While the purpose of imposing a limit on the insurer's obligation should be sympathetically admitted as an influence on the issue as to whether there is such a limitation, the same consideration does not apply to the issue of the degree of the limitation. As the construction advanced by the insurer has a more restrictive effect on the indemnity to be provided than the alternative construction to which the expression is open, it might be thought that the one adopted should conform to the thrust of its immediate purpose, that is, to enlarge the insured's cover. To construe the limitation aspect expansively in favor of the insurer runs counter to this, and this weakness is particularly important in its competition with the claims of the insured to the dominance of the positive aspects of cover.

This approach is in conformity with high Australian authority, ${ }^{21}$ which, in respect of exclusion and limitation clauses, ${ }^{22}$ has pointed out that the decisions clearly establish that the interpretation of such clauses is to be determined by construing the clause in accordance with its ordinary and natural meaning, read in the light of the contract as a whole, so giving due weight to the context in which the clause appears, including the nature and object of the contract and, where appropriate, construing the clause contra proferentem in case of ambiguity. It is also in conformity with the general trend to adopt the construction more favorable to the insured referred to in Federico. ${ }^{23}$

Even if this very important consideration were disregarded, on this issue as to the connotation of the expression, the weight of commercial purpose should favor the insured's position because of the primacy of the policy's purpose of covering loss over the subsidiary purpose of limiting the insurer's liability in that respect, and the even more secondary aspect of extending that limitation to unusual circumstances. The choice as to the preferable construction should attribute greater weight to the primary purpose. ${ }^{24}$

The "Pearl Harbor" argument has some superficial attraction, but it relates to a totally different factual context, far removed from that of an

21. See Darlington Futures Ltd. v. Delco Australia Pty Ltd. (1986) 161 CLR 510.

22. To the extent that the relevant clause here has the effect of limiting the extent of the amount of the insurer's obligation, it comes within this description in substance.

23. See Federico, 160 CLR at 520.

24. This argument, and its derivatives suitable to the occasion, does not seem to have been considered in the authorities. The reason may be that it is so untenable that it was not even advanced, but then its subtlety may have meant that it was overlooked in favor of other reasons to the same result. 
insurer's agreement with its insured to provide indemnity against loss. In a judgment approved by the Court, ${ }^{25}$ Waller LJ said:

[The word 'event'] in its ordinary meaning can describe an historical event like the Hundred Years War. But since the clause in an insurance contract is concerned with losses arising out of an event, that context 'straightaway implies some causative element and some degree of remoteness, or lack of remoteness, which must be established in the circumstances of the particular case. ${ }^{26}$

The Hundred Years' War is certainly different from a sustained attack over a brief period of time, as in Pearl Harbor and in the present case, but the same discrimination would see a difference between Pearl Harbor and this case. Further, it should not be assumed that Pearl Harbor should be considered as a single occurrence for all purposes. If it is considered simply in relation to occasions of damage to property as a general focus, it is very debatable whether it should not be regarded as a series of occasions of such damage from a common cause. A fortiori if is considered in the context of an insurance contract under which the parties were arranging the indemnity for the loss of property from separate occurrences.

In this, it is suggested, lies the solution to the issue. The construction must be influenced by the commercial insurance context in which the words were agreed. It did not receive specific attention in recent English cases that are very much in point, particularly because they discuss the meaning of "occurrence" in the context of a first-party policy for indemnity against property loss, though the conclusion and reasoning of the last three, the most authoritative, are mostly reflective of this approach.

In Dawson's Field Award ${ }^{27}$ Sir Michael Kerr confronted the question in respect of loss suffered as the result of the destruction of four hi-jacked aircraft, one of which was blown up at Cairo airport, and three at Dawson's Field. The relevant passage of the policy referred to loss sustained in respect of "each and every loss ... and/or occurrence and/or series of occurrences arising out of one event." 28

He was plainly moved by the integration of the event in continuity of time and action. He said:

25. See R.E. Brown v. GIO Ins. Ltd. C.A. 17, at 5 (Cal. Civ. 1998).

26. See Caudle v. Sharp (1995) Lloyd's RLR 433, 438 per Evans, L.J. (Evans, L.J., also pointed out that the First World War and even the Ice Age could be called an event, but not in such an insurance context).

27. See Dawson's Field Award, Mar. 29, 1972.

28. Id. 
I consider that I have two approach the present problem by putting myself in the position of an informed observer at Dawson's Field on 12th September 1970, watching the preparations for the blowing up of the aircraft, the evacuation of the immediate vicinity and the blowing up of the aircraft. During this period he would of course have seen in a multiplicity of actions and events including a number of separate explosions which destroyed the aircraft. Would he then say that they destruction of the aircraft was one occurrence or a series of occurrences? The answer must be subjective. No one contended that each explosion was a separate occurrence. In my view there was one occurrence, one event, one happening; the blowing up of three aircraft in close proximity more or less simultaneously, within the time span of a few minutes, and as a result of a single decision to do so without any one being able to approach the aircraft between the first explosion and their destruction. I cannot regard this and as a 'series of occurrences'...

I have already dealt with the Respondents' contention that the proximate cause of the destruction of the aircraft were [sic] the hijackings, which I cannot accept. I accept their contention that if the aircraft became total losses by hijacking [which I reject] then the hijackings could not be aggregated for any purpose under the Clauses. It would be impossible to treat the hijackings as a single occurrence. I also reject the contention faintly and more or less formally advanced by the Claimants that the hijackings arose out of one event, viz. - the PFLP' s overall plan. I agree that the plan cannot by itself constitute an event. But it was then said on behalf of the Respondents that the destruction of the aircraft at Dawson's Field could also not be said to have arisen out of one event, because the only unifying event could have been the decision or order to blow up the aircraft. But in my view this approach is much too narrow, though this view must admittedly be coloured [sic] by my view about 'occurrence'. The destruction of the aircraft arose from the decision or order to detonate the explosive charges in them which was thereupon carried out in the way described above. If three aircraft become total losses because of a decision or order to 
blow them up together is carried out, why is the carrying out of the destruction or order not one event? ? $^{29}$

In Kuwait Airways Corporation v Kuwait Insurance Co ${ }^{30}$ the Court analyzed the authorities on the meaning of "occurrence" in the insurance context in respect of the capture and removal of a fleet of Kuwaiti aircraft by the invading Iraqis. The relevant phrase was "any one occurrence, any one location," and the question was whether the capture of fifteen aircraft that Kuwait airport was one occurrence or fifteen occurrences. Rix J. said:

It seems to me that these authorities justify the following proposition. An 'occurrence'(which is not materially different from an event or happening, unless perchance the contractual context requires some distinction to be made) is not the same as a loss, for one occurrence may embrace a plurality of losses. Nevertheless, the losses' circumstances must be scrutinised [sic] to say whether they involve such a degree of unity as to justify their being described as, or as arising out of, one occurrence. The matter must be scrutinised [sic] from the point of view of an informed observer placed on the position of the insured. In assessing of the degree of unity regard may be hand to such factors as cause, locality and time and the intentions of the human agents. An occurrence is not the same thing as a peril, but in considering the viewpoint or focus of the scrutineer one may properly have regard to the context of the perils insured against. ${ }^{31}$

The last allusion clearly relates to the nature of the policy and the influence that that feature has upon the construction of its terms. The need to have regard to the insured's point of view in discriminating between the undoubted variety of connotations of the term had been earlier explained when, after referring to analogous examples such as air-raids or a submarine attack on a convoy, he said:

On which side of the line each of these is to be placed depends... on the position in which the person who has to

29. Id. It is a pity that he did not place the trained observer in the position of an observer of the conclusion of the contract, and contemplated what the observer would have thought the parties objectively intended as to the meaning of occurrence in that context in relation to events such as he recounted.

30. See Kuwait Airways Corp. v. Kuwait Ins. Co. (1996) 1 Lloyd's Rep. 664.

31. Id. at 686. This identification of the element of unity is adopted and applied in Mann v. Lexington Ins. Co. C.A. 256 (Cal. Civ. 2000) 
make the determination is placed and on the way in which he will therefore approach the question. The crews of a submarine and of ships which are attacked and sunk in a convoy would no doubt regard each attack and sinking as a separate occurrence. An admiral at Naval Headquarters might regard the whole attack and its results as one occurrence; a historian almost certainly would. An earthquake may have a number of tremors producing different times and in different places; the victims would no doubt regard each tremor as a separate occurrence but others might not. Whether or not something that produces a plurality of loss or damage can properly be described as one occurrence therefore depends on the position and viewpoint of the observer and involves the question of the degree of unity in relation to cause, locality, time, and, if initiated by human action, the circumstances and purposes of the persons responsible. $^{32}$

His various references to cause, locality, time and the intentions of the human agents have countervailing influences in the present case. In respect of each loss, the cause was a separate act of destruction, which was reflected in some time difference, and although that interval was relatively small and both attacks were all part of the same overall plan, the perpetrators of the actual destruction were respectively engaged on different missions despite their common purpose and related performance. It is not as though they had control of the whole area and carried out their several acts of destruction as part of a unified and integrated act, such as the controlled and progressive destruction of several items of property in their hands. ${ }^{33}$ There was a certain unity of location in that the two buildings were part of the same complex and adjacent, and as such represented a single icon that was intended to be destroyed in total; but each was a separate structure that required a separate attack for the purpose of the overall plan, and, from the insured's point of view, represented a separate item of property that was lost.

Another precedent that is somewhat but imperfectly analogous, is to be found in Mann $v$ Lexington Insurance Co. ${ }^{34}$ where the insured's properties that were located in different places in a single country were destroyed over a period of two days in riots that were said to be part of a single planned purpose, but the occasions of destruction were found to amount to separate occurrences. The differences in location and time from those features in the present case are apparent, but the differences in degree do not necessarily

32. Kuwait Airways Corp.,1 Lloyd's Rep. at 685.

33. As was the position in this Kuwait case and in the Dawson's Field Award, to which this judgment referred.

34. See Mann v. Lexington Ins. Co. C.A. 256 (Cal. Civ. 2000). 
constitute a difference in kind in respect of those elements. The unity of purpose of the perpetrators was identical in principle, and this authority establishes that it alone is not decisive. The result depends on the totality of the relevant elements and their relative weights in the context of the relevant point of view.

Another possible analogy that deserves investigation is the infliction of two distinct episodes of damage during the course of a single storm. Care must be taken to ensure the quality of the analogy by eschewing circumstances where the distinct episodes of harm are the progressive consequence of a continuous destructive force, such as the erosion of the support of a building that causes sequential episodes of damage as the removal of support reaches distinct critical stages, each leading to partial and progressive damage. More analogous would be the causing of separate damage to different buildings during one storm by separate lightening bolts or by two separate flood surges.

The insured will be comforted by a well-known New York case ${ }^{35}$ where two "accidents" were found when two adjacent buildings of the insured were successively damaged when protecting walls of their respective basements collapsed, with a fifty-minute interval, from the flooding of a single construction trench by the waters of a single rainstorm. The decision seemed to rely on the separate occasions of destruction of the respective walls, the risk of which feature was, of course, the focus of and raison d'etre for the insurance cover. The present circumstances favor the insured's case even more because in the case cited, the destructive force, the flood, was continuous and operative on both properties at the same time. Here, the application of destructive force was distinct and separate on each occasion, which enlarges and emphasizes the feature of separateness.

There are some other precedents providing reasoning that by analogy serve as a useful guide, but their use must be accompanied by the usual strong caveat against the automatic adoption of the construction in another case of a different, or even an identical, form of words in a different grammatical and circumstantial context. ${ }^{36}$ It is nevertheless useful to consult analogous cases on the use of this term in liability insurance cases, not for the meaning of the word but for the principled approach to the task of construction. In this exercise, however, it is vital to observe the distinction between the peril covered by such policies and that in the present case.

The principle is the same and the result will be seen to be the same providing the peril is correctly identified. In first party cover, essentially the insurer promises to pay money on the happening of an event that causes loss, the risk of which has been insured against. ${ }^{37}$ It follows that this feature must

35. See Arthur A. Johnson Corp. v. Indemnity Ins. Co., 164 N.E.2d 704 (N.Y. 1959), 7 N.Y.2d 222.

36. See Fire \& All Risks Ins. Co. Ltd. v. Powell (1966) VR 513, 517; Montrose Chemical Corp., 913 P.2d at 878.

37. See id. 
have considerable influence when the issue is the construction of the reference to an "occurrence" that is related to the determination to the amount of the indemnity that the insured is to receive.

Here the peril is the insured's loss through the destruction of or damage to the insured property and the occurrence that is relevant is that which is proximately causal of that harm, even though the initiating cause may be removed in time and the harm may be delayed. If a building catches fire through faulty electrical wiring performed some years before, the relevant occurrence is the fire and not the electrician's remote negligent act or omission, despite that the latter was the cause of the former.

In liability insurance, the peril is the insured's loss through incurring liability to a third party. ${ }^{38}$ Sometimes that liability arises through the insured's negligent infliction of harm on the person or property of the third party, and again in those cases, the liability is incurred, not necessarily when the wrongful act is committed but when it causes damage to the other that gives rise to the liability. In that situation, the occurrence is the mishap causing the injury and not the injury itself. ${ }^{39}$ This has a profound effect on the construction of "occurrence" in that context because the occurrence that must have the relevant causal nexus with the peril is the happening of harm to the third party, and not necessarily the occurrence of the insured's act or omission causing that harm, which may be more remote. ${ }^{40}$ This construction is based on business efficiency and reasonableness. ${ }^{41}$ This is vital in some cases where the requirement that the occurrence trigger must be within the policy period has led to litigation on this issue.

In this context, it has also led to the result that in respect of a mishap/collision involving a vehicle causing separate injury to several people, it has been found that there have been several 'accidents,' whereas when a vehicle struck one person who then struck another and they both fell under the wheels of the vehicle, there was but one "occurrence."42 The influence of the purpose of the policy on this construction is manifest throughout the judgments of the Court of Appeal in the Tramways case. In Lord Esher M.R.

38. The delay in the insurer's obligation to provide indemnity until the establishment of that liability through judgment, award, or settlement is a different matter and not relevant to this issue.

39. See Forney v. Dominion Ins. Co. Ltd. (1969) 1 WLR 928, 934.

40. See Loughelly Iron \& Coal Co. v. McMullen (1934) AC 1; Williams v. Milotin (1957) 97 CLR 474, 565; Bowling v. Wienert (1978) 2 NSWLR 182, 291; FAI General Ins. Co. Ltd. v. Hendry Rae \& Court (1993) 115 FLR 50, 67, 74; GIO General Ins. Co. Ltd. v. Newcastle City Council (1996) 38 NSWLR 558, 572, on app (1997) 191 CLR 84; Della Vedova v. HIH Casualty \& General Ins. Ltd. (1997) 9 ANZ Ins. Case 61.383; Windsurf Pty Ltd. v. HIH Casualty \& General Ins. Ltd. (1999) 61.447.

41. See GRE Ins. Ltd. v. Bristile Ltd. (1991) 5 WAR 440.

42. See South Staffordshire Tramways Co. Ltd. v. Sickness \& Accident Ass. Assn. Lid. (1891) 1 QB 402; Allen v. Land Guarantee \& Accident Co. Ltd. (1912) 28 TLR 254. The latter purports to follow the former, but the distinction is very fine and even doubtful. 
in his very brief judgment began by reciting the nature of the insuring clause of the policy that spoke of claims for personal injury made against the assured in respect of accidents caused by its vehicles.

In fidelity and employee dishonesty cover, a limit as to the amount of the cover will usually be set by reference to an "occurrence," but in that class of insurance there is only one covered "occurrence" in a series of embezzlements by an employee pursuant to a common scheme or episode of dishonesty. ${ }^{43}$ It is recognized in the authorities on the subject that this result will vary between different classes of cover, and in this class, it is not surprising to find such a result because the concept of occurrence is more closely associated with the defalcations of the employee, whereas in the World Trade Center cover, it is associated with the destruction of the insured's property.

There are some other useful references of oblique, and therefore limited, relevance. For example, Axa Reinsurance (UK) Ltd $v$ Field ${ }^{44}$ has limited utility because of the constricting nature of the form of the hearing before the House of Lords, and the issues involved. However, after reaffirming that an excess of loss reinsurance policy need not be assumed to follow the original policy as to the risk covered, the House pointed out the obvious, that an "event" is not the same thing as "an originating cause." "In ordinary speech, an event is something which happens at a particular time, at a particular place, in a particular way." 46 And "a cause is . . . something altogether less constricted." 7 "It can be a continuing state of affairs; it can be the absence of something happening." ${ }^{8}$ That was sufficient to resolve the issue there, and it is of limited use here in its emphasis on the difference between an event and its cause and how the nature of the two may vary.

There are several other cases involving the issue of what is comprehended by "a series of occurrences," often qualified by association with a common causal nexus, when that expression appears in a policy, but usually their discussion is predicated upon the acceptance that the occurrences are separate, and any discussion on the meaning of "occurrence" may be

43. See Business Interiors Inc v. Aetna Casualty \& Surety Co., 751 F.2d 361 (10 Cir. 1984); Christ Lutheran v. State Farm Fire \& Casualty, 471 S.E.2d 124 (N.C. Ct. App. 1996); Valley Furniture v. Transportation Ins. Co., 26 P.3d 952 (Wash. Ct. App. 2001); Jefferson Parish v. Fidelity \& Deposit Co., 673 So.2d 1238 (La. Ct. App. 1996); Howard Weil Labouisse Friedrichs v. Ins. Co., 557 F.2d 1055 (5th Cir. 1977); Peco Energy Co. v. Boden, 64 F.3d 852 (3rd Cir. 1995); American Commerce Ins. v. Minn. Mut. Fire, 551 N.W.2d 224 (Minn. 1996); Pasternak v. Boutris, 99 Cal. App. 4th 907 (Cal. Ct. App. 2002). But see Slater v. U.S. Fidelity \& Guaranty Co., 400 N.E.2d 1256 (Mass. 1980). This case stands alone and does not appear to be correct.

44. See Axa Reinsurance (UK) Ltd., 1 WLR at 1026.

45. Id.

46. Id.

47. Id.

48. Id. 
contaminated for present purposes by the serious difference of the context and the purpose of the relevant provision. This said, it may well be a powerful argument in favor of the view taken above that it was open to the insurer to use such a reference to a series if it were intended to comprehend a number of arguably separate events within a single trigger of cover; and it failed to do so. The obvious inference is often favored by the judges in construction issues.

\section{CONCLUSION}

If the World Trade Center litigation were to be held in Australia or England, the result would probably favor the insured for two main reasons in principle:

- Having regard to the commercial purpose of the policy, an objective view of the meaning of "occurrence" in this context, but taken from the insured's point of view, would not attribute to the expression an extension of the insurer's limitation of its obligation that would roll these two occasions of destruction into one for the purpose of the limitation. Rather, the tenor of the provision at the point of the use of the expression is towards enlarging the extent of the cover.

- The relevant factors do not exhibit such a degree of unity of the total occasion to justify its denotation as one "occurrence" within its meaning in this context. 